\title{
しキニーネ皮レサリチール酸の聽覺に 及ぼす影響に就ての賽驗的研究
}

\section{$\mathrm{V}$ 聽神經中樞領域に於ける病理組織學的所見}

大學院學生 長 澤 芝 郎

[京阯帝國大學覴祭部耳鼻㸶喉科教室(星野教授指導)]

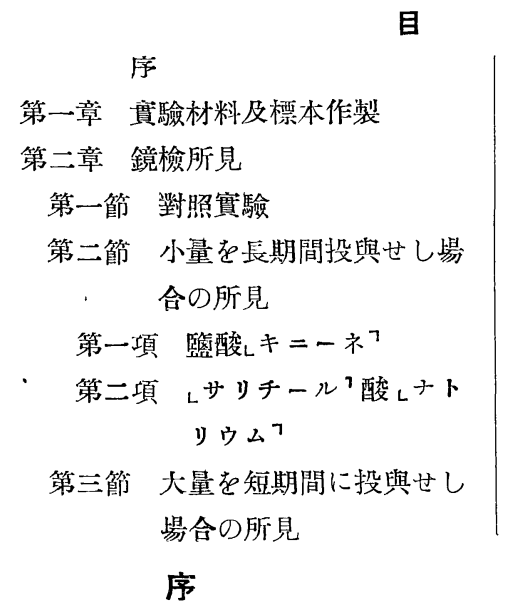

溜に余は鹽酸亡キニーネフ及びレサリチ 一ルフ酸しナトリウムフによる音響性耳殼 反射の影響を觀察し, 次で㯖器の病理組 織學的檢索を行ひて該部に於ける變性を 確證し得たり．低つて本編に於ては原形 質表をるレキニーネ站びにレサリチールフ 酸が聽神經中樞領域に如何なる影響を及 ぽすかを知らんと欲し，本實驗を企たり。

\section{第一章 實驗材料及び標本作製}

材料は第三編に於て使用せし動物の延 䯣, 中腦, 間腦及大腦とす。材料は可及的 小塊片とし，レアルコホールフ沙滌を行ひ
次

第一項 鹽酸

第二項 レサリチールフ酸レトナ リウム

第四節一定度減弱せし聽覺の恢 復せし昜合の所見

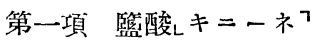

第二項 よサリチールフ酸しナト リウム

第三章 綜括站に考按 第四章 結 諭

しものにてはょアルコホールフ後固定, 重 レクロム 酸加里とょフオルマリ゙ンフ水混合 液洗滌のるのにてはウイツトマツク氏液 後固定及びレオスラウム 酸處置を行ひて 以後水洗脫水等型の如くに從ひ, レツェ口 イヂンフに封固す。レフオルマリンフと蒸 溜水混合液洗滌のものは凝結橪本を作製 す. 染色は $1.1 \%$ レトルイヂンブラウר 染色. 2。 レヘマトキシリンエオデンフ 重 染色. 3. ᄂマルキー顆粘の檢屾. 4. レワ イゲルトパール氏骨道䩗染色法を施行す.

\section{第二章 檢 鏡 所 見}

第一節 對览 實䮦 
滅第生理的食鹽水 $1 \mathrm{cc}$ 万至 2cc 試獸 の腹腔に注入し, 10四防至20包後の動物 の腦質を檢鏡す。

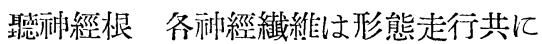
正常にしてレマルキー顆絃を證せず.

踾神經腹核 及背 核：各神經節細胞の シツスル氏小體は染色稍不良なるものあ り。顆䊀は微細状を呈し周邊性に稀に中 心性に分有し，又は集簇す，原形質の形 態に異狀なく，核丈著變なし，神經纎維 正常にしてレマルキーフ 顆粒の出現なく レグリアフ組織又異祆なし。

上檄欖體：神經細胞は極稀に秒萎縮す. 核核質に異状なく，僅にニツスル氏小體 の染色不良なるもの西り．然れ共神經繊 維正常にしてレグリアフ組織の増殖なし.

前短神經核：神經細胞の形態は正常な るも稀汇過染するを認む。三ツスル上小 體の形状，染色其に異状なし，核の染色 秘不良なるものあり。神經纎維は一般に 正常なるる 1 例に於て染色微弱にして櫵 かに鬆疎を呈するものあり：レマルキーフ 顆粒なく，レグリアフ組䘹又異状なし。

顏面神經三文神經及外旋神經各核・核 質に著變なし. 核の濃染するものを混ず。 シツスル氏小哣概して正常にして顆粒は

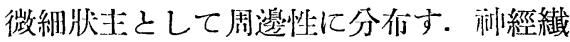
維に異狀なし。

中腦, 外側蹄係, 後四疊體: 核及核質に 異㹜なし. 三ツスル代小绸の稍微染する ものあるも概して正常なり、种經纎維は
正常なる爿態を呈し，ムマルキーフ顆粒及 びレグリアフ組織に異變を認めず。

間腦, 內滕壯體：祈經纎維の形態走行 共に正常子り。胞體, 核及三ツスル氏小體 には認むべき變化なし。

終腦・䫘㛲葉部の分子庴，大小各錐體 祈經細胞層及び多型細胞層に於て小數胞 體の㘺かに萎縮の狀を呈するものあり. ニツスル氏小體の稀に微染するものある も核及び核質に著變なく，神經繊維又異 状なし。

第二節 小量を長期間投與 せし場合の所見

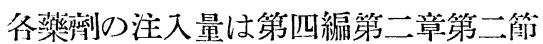
に同じ.

第一項 鹽酸しキニーネフ

檢鏡所見

聽神钦根：各神經纎維の排列稍不規则なる も菱繀するものなし、稀に鬆踈の感を抱かし むるものあり・一般に前庭神經は蝸牛款神經 に比り變化輕度なり。

聽神經腹核及聽結節：神鱼節細胞は輕重種

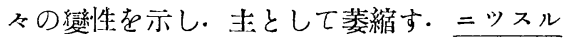
氏小體は概して染色不良なるも稀に濃染す。 顆粒狀物筫一定せすして䐍大又は微細狀とな ๖，廣沉性に或は周邊性に散在す。稀に一部 に集簇す。原形質及核の染色一羕ならす，稀 に核の崩壞像を呈するものあり・之等の變化 は腹核に於て稍高度なる感あり・神徑繊維は 排列不規则にして箖踈なり・染色亦微弱なり. 而して之等の變化は繊維走行の內側に於て稍 顯著なる感あり・ムグリアフ組織の增殖なく僅 かにレマルキー7顆粒を涊む. 主として腹核部 に存す。

モナコウ，ヘルド氏聽線及菱形體：繊維は 稍蛇行狀を呈し，染色は概して不良なり・1 
例に於て菱形體に僅少のしマルキーフ顆粒を認 む.

上橄㰖體：胞體は形態正常なるも一般に過 染す. ニッスル氏小體は濃淡㮔々に染色し, 概して廣沉性に微細顆粒㹜を呈するも稀に周 邊部に集簇す・神俓繊維の走行稍不規則なる を染色は概して可良なり・しマルキーフ顆稙の 出㠫なく，レグリヤフ組織又異狀なし.

前庭神涇核：胞體の形態正常なるも濃染す るもの多し. 稀に核の淡染し，文消失するも のを認む. ニッスル氏小體は微細顆粒狀とな ๖，周邊部に集簇するもの多く，稀に廣汎性 に又は中心性に存在す。染色は概して過染な ๖・神溜纎維の蛇行狀を呈するものあるも染 色は不良なら.レマルキーフ顆粒の出現なし.

顏面神签, 三叉神經及外旋神涇各核: 三叉 及び外旋神經核の胞體は正常なるも顔面神經 核の染色稍不良なるものあり.ニッスル氏小 體, 微細顆粒狀となり周邊部或は中心性に分

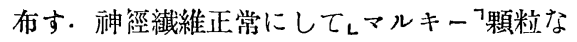
く，レグリヤフ組織丈異常なし.

中垭, 外側蹄係, 後四嘼體: 神徑節細胞の形 態正常なるも染色稍不良なるす心存す。核は 概して濃染す. 三ツスル小體の染色不良なる もの多く主として顆粒は周邊部に分布す. 神 經繊維は全く正常にしてしマルキー7顆粒の出 現を見す。

間腦，內膝狀體：胞體は稍萎縮の感あるも 原形質，核共に著變を見す・ニッスル氏小體 の染色不良なう・神經纎維に異常を認めす。

終腦：䫚霣葉部に於ける分子層，大小錐體 神陘細胞層及び多型細胞層の各胞體中に稍萎 維するもの稀に膨大するものあり・一般に染 色可良なるも核は濃染す・ニッスル氏小體は 濃淡種々にして微細なる顆粒狀となり，周邊 性に又は桷夢性に分布す、極稀に顆粒の崩壤 するを認む・神經繊維は排列染色共に著變な く，レマルキーフ顆粒及びレグリアフ組織の增殖 を認むる事なし。
第二項 Lサリチール7酸しナトリウム

檢鏡所見

聽神經根：各神經纎維稍蛇行狀を呈し，箖 踈なり，前庭，蝸牛兩神經繊維間に變性の差 異は涊めがたし。

聽神經腹核及聽結節 : 兩种涇節細胞は圭と して萎縮す. ニッスル氏小體の染色力は一般 に微弱なるも之等の間に濃染せるものを混入 す. 顆粒は微細狀となり沓として廣沉性に分 布す. 稀に顆糔の洧蔓性に染色し, 模糊とし て顆粒の識別されざるものあり．原形質の形 態は正常にして核の濃染するもの散見す。 之等の變化は概して腹核に著明なる・神經繊 維の走行稍不正にして稀に空隙を形成す・染 色亦不良なるを認む。

モナコウ，ヘルド氏聽線及菱形體：繊維間 に間隙を認めらる・染色は概して可長なる。 レマルキーフ顆粒の出現を見す。

上橄欖體：胞體の稀に膨大するものあり. 概して過染す。ニッスル氏小體亦染色一定せ す，濃淡相混入し，顆粒は微細狀となりて周 邊性に分布す・神經纎維の走行概して正常な り. 染色の微弱なるものを涊む. ᄂマルキーフ 顆粒及

前庭神經核：胞體の形態は概して正常なり。 核は寸として過染するを認めらる。ニッスル 氏小體は微細狀となりて周邊部に分布し, 稀 に中心性に集簇す・顆粒の濃染するもの多し。 柛經繊維の稀に走行不正なるものあるも染色 は一般に可良なり・レマルキーフ顆粒を認め す

頝面神弳，三叉神經及外旋神誙各核：各胞 體の形態に異狀を認めす. 染色亦概して可良 なり・ニッスル氏小體の稀に微染するものあ ๖. 顆粒は微細狀となり, 周邊性に又は一部 に分布或は集簇す。神經繊維は正常なり。

中腦, 外側蹄係後四嘼體: 神經節細胞の稀 に萎縮するを認む。染色は一般に可艮なり。 核は概して過染す。三ツスル氏小體は染色稍 
微弱なるも顆粒は廣汎性に分布す, 神涇繊維 又正常なり・レマルキーフ顆粒の出琴なし.

間䐳，內膝狀體：胞體，核共に著變老見す。 ニッスル氏小體の一部に染色不良なるものを 認さ・神經纎維の走行排列共に正常なり。

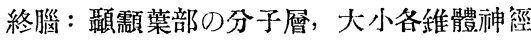
細胞層及び多型細胞層の备胞體巾，稀に萎維 又は膨大するものあり・多く過染す・三ッス 儿氏小體入濃染するものを混入す・微細なる 顆粒は土として廣沉性に分布す・神無纎維に 著變なし・レマルキーフ顆粒及びレグリアフ組織 の增殖を認めす。

第三節 大量を短期間に投與 せし場合の所見

\section{各藥劑の注入量は第四編第二章第三節} に同じ.

$$
\text { 第一項 覧酸 } キ \text { キーネフ }
$$

\section{檢鏡所見}

聽神徑根：蝸牛殻神涇繊維の一部に於て排 列の鬆疎なるも0あるも前庭神徑纎維は正常 にして且共にしマルキーフ顆粒の出現を見す。 聽神”鱼腹核及背核：各神徑節細胞の胞體中 菱縮するもの稀に版大するものを散見す，核 は濃染又は微染し胞體の染色は不良なり・腹 核に於て稀に核の崩壞する垛む.ニッスル 氏小體は俓重種々なる變性を呈し染色亦不良 なり。該小體は微細顆粒狀となり，圭として 周邊部に分布するも稀に廣沉性に又は中心性 に散性して集簇す、稀に之等變性せる節細胞 中に侗正常なる胞體の混入するを認む・ ニッ

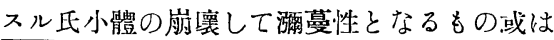
染色の淅く認め得るもの老極稀に散見す。神 經瀻維は排列正常なるも走行の稍蛇行狀を呈 するものあり・

モナコウ，ヘルド氏聽線及菱形體：各神經 繊維正常にして認むべき變化なし・且しマル キーフ 顆粒を證明せす.

上数欖體：胞體の形態は略正常なり．染色
は一樣ならす・概して過染す・核は一般に微 染す. ニッスル氏小體は微細又は粗大顆粒狀

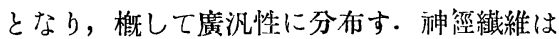
一般に正常なるも1例に於て染色稍微弱のも

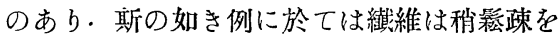
呈す・レマルキーフ顆粒の出兒なくょグリヤフ組 織又異㹜なし。

前庭神經核・胞體は正常なるも僅かに核質 の染色不良なるを認む・核は一般に濃染す。 ニッスル氏氐小體は粗大或は微細顆粒狀となり 周邊部に分布す.染色は概して微染す・神經

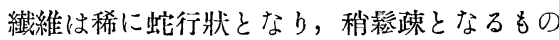
あるも概して正常なり・ムマルキーフ 顆粒な し.

顏面神經，三叉神涇及外旋神徑各核：核質 は正常なるもニッスル氏小體の染色不良なる ものあり・核に著變なし・レグリヤフ組織の增 殖を認めす。

中腦，外側蹄係後四嘼體：神經節細胞の形 態染色共に正常なり・ニッスル氏小體は微細 顆粒狀となり，稀に膤蔓性となりて微染する ものあり・然れ共神鱼㵶維異狀なく，マルキー 顆粒の出現を見す。

間腦, 內膝狀體・神涇細胞の核及び核質共 に正常にして ニッスル氏小體又異狀なし．神

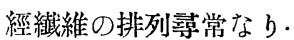

終腦：頜塞部に於ける分子層小及び大錐體 細胞層端びに多型細胞層の胞體の形態は正常 なるも染色は過染するもの多し.ニッスル氏 小體丈過染し, 微細又は粗大顆粒狀を呈し, 周邊部又は中心性に分布す・神經繊維の排列 染色共に異狀を認めす。

第二項 Lサリチール酸レナトリウム

檢鏡所見

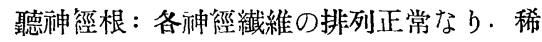
に走行の稍蛇行性を呈するものを認め，且少 量のレマルキーフ顆粒を見る。

聽神徑腹核及背核：神徑節細胞の胞體は僅 かに膨大す・核は濃染するもの多く，稀に微 染す・ニッスル氏小體の染色は一樣ならず, 


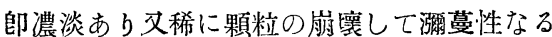
ものあり・顆粒は主として微細狀となり，周 邊部に分布す.神'涇瀻維の排列は正常にして 染色文可良なり.

モナコウ，ベルド兩聽線反菱形體：各神徑 繊維に異狀を認めす。レグリヤフ組織の恝殖な ᄂ.

上:檄㰖體：胞體の形態正常にして染色又概 して可良なり・核の微染するものあり，概し て濃染す.ニッスル氏小體は主として微細狀 そなり，概して周邊性に分布す、神經繊維の 稀に蛇行狀を呈するものあり・少音のしマル キーフ 顆粒を見るものあり.

前庭神涇核：胞體は稍膨大の感あり. 稀に 萎縮するを認む・核は一般に濃染す・师 几氏小體は粗大又は微細狀となりて周邊部に 分布し，父中心性に集簇す。染色は濃淡相混

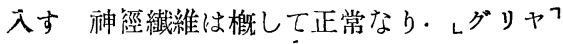
縕織の霄殖を認めす。

顏面神”經，三叉神"缰及外旋神涇各核：胞體 の形態に異常を認めす. 染色稍微弱のものを 散見す・ニッスル氏小體の染色亦不良なり・

核に著變を見す。

中腦，外側蹄係，徭四疊體：胞體の形狀は 正常なり・ニッスル氏小體は濃染するも稀に 瀰暮性に淡染するものあり．神俓繊維の排列 走行共に異狀なく，レマルキーフ顆粒の出現を 見す。

間腦, 內滕狀體: 神經細胞の形態染色共に 黑狀なく，核又正常なり。神涇纎維は正常な る狀態を呈す・レマルキーフ顆粒の出現を衿め †.

終腦：形頁颥葉部の分子層，大小錐體神經細 胞層及び多型細胞層の各胞體の形態は正常な ろ. 染色は土として可良なるも稀に過染する を認む. ニッスル氏小體は微細狀となりて廣 沉性に分布するを常とす．少數例に於て周邊 部に又は中心性に顆粒は集簇す・神經繊維に 異常を認むる事なし。
第四節 一定度に減弱せし德覺の

恢復せし場合の所見

各藥贸の注射量は第四編第二辛第四節 に同じ。

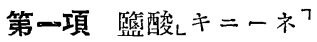

檢鏡所見

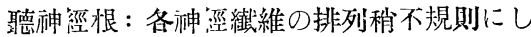

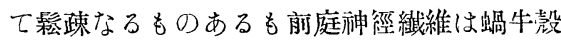
神經繊維に比し變化輕度なり。

疆神”涇腹核及聽結節：神涇節細狍性輕度な る變性を示す・節胞體は僅かに腫脹し又は萎 維す。・ッスル氏小體の染色一般に不良にし て分布狀態丈不規則なり。毁微細顆粒狀とな りて廣沉性なるもの或は麼㨾の顆粒狀となり て胞體の周邊部に又はその一部に集簇す。劣 高度なる變泩に於ては顆粒の崩壞するものあ ๖.之等の所見は概して腹核に著しきを常と す. 原形筫の染色亦不良なるも稀に濃染す。 之等變生せる細胞中に尙正常なるものを認 む. 神徑繊維の稀に鬆柾蛇行狀に匐走するも のあるも概して著變なくしダリヤフ組織の堌殖 なし.

モナコウ，ヘルド氏聽線及菱形體：各神徑

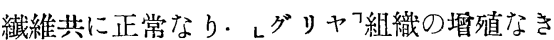
も1例に於て僅にしマルキー顆粒を認む.

上橄㰖體：胞體は稀に萎縮し，一般に濃染 す・核質は多く菱縮し核は主として偏在する も少數例に於て核の消失するものあり・ニッ スル氏小體は濃染又は微染し，不規则に分布 す. 郎顆粒は粗大又は微細狀となりて散在し 稀に濑蔓性となる。神涇纎維は 1 例に於て紡 錘狀を呈し丈は箖柾となるものあり。

前庭神經核：胞體は淡染，僅かに菱縮す ニッスル小體は周邊部に集簇或は濔蔓生に分 布す. 染色は概して濃染す. 神經繊維の排列 稍不規則のものあり・しマルキーフ顆粒及レグ リャフ組織異狀なし.

顏面神徑，三叉神钷及外旋神徑各核：胞體 は略正常なり・ニッスル氏小體の染色稍不良 
なるもの認める外核質に異狀なし.ムグリ ヤフ組織に著變を認めす。.

中腦, 外側蹄係, 後四疊體: 胞體の形態 正常染色又可良なるもニッスル氏小體稍微染 するものあり・核質に著變なし・神經纎維丈 正常なり・

間腦, 內腅状體：神經繊維に異狀を認めす。 神經節細胞は原形質，核共に變化なく，三ツ スル氏小體亦著警なし.

終腦：上側頭廻轉中部に於りる分子層，小 及大錐體神涇節細胞層站びに多型細胞層の胞 體の形態に異狀なし.染色稍不良のものあり. シッスル氏小體の濃染するものあり・顆粒は 概して微細にして圭として周邊部に分布す. 神經繊維は正常にして他に著變を涊めす。

第二項 しサリチール7酸しナトリウム 檢鏡所見

聽神䋊根: 神徑繊維の稍不規則なる排列を 呈するものあり．前庭及蝸牛兩神經緎維の變 化に差異を認めす。

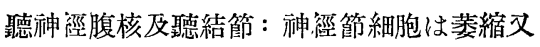
は膨大するもの混入す・染色は僅かに不良 なり・ニッスル氏小體の染色は一般に微染す。 該顆粒は土として微細狀となりて廣沉性に稀 に周邊部に散在し又は集簇す・極稀に顆粒の 崩壤して認め難きものある・核は一般に淡染 す.神經繊維の蛇行性に走行するものある。 レグリヤ7組織に異狀なし.

モナコウ，ヘルド兩聽線及菱形體：各神經 纖維共に正常なり.

上橄欖體：胞體は稀に菱縮し稀に膨大す。 核筫, 及び核の染色は一般に微弱なるも亦濃 染するを認む・シツスル氏小體は不規則に分 布し, 圭として微細顆粒狀を呈す.稀に顆粒 の消失するを認む. 神經繊維は概して正常に して他に著變なし.

前庭神經核：胞體は稍微染し 僅かに萎緒 す. シッスル小體は土として周邊部に分布し 又は中心性に集簇す・神經繊維の排列不規則

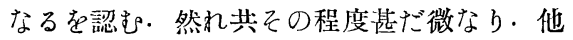
に異狀なし.

顏面神經, 三叉神”铥及外旋神經各核：神經 細胞は凡て正常にしてニッスル氏小體又著變 なし。

中腦, 外側蹄係, 後四鱟體: 神徑節細胞の形 態, 染色共に正常なり・ニッスル氏小體の稍 微染するものあるも核質に異狀なし. 神經繊 維又正常なり.

間腦, 內滕狀體：胞體核共に變化なく, 三 ッスル氏小體亦正常なり・神經纎維の排列走 行共に異狀を認めす。

終腦：䫚需葉部の分子層, 大小錐體細胞層 站びに多型細胞層の神經細胞體の形態に異狀 なく，染色亦概して可艮なら・ニッスル氏小 體は淡染又は濃染するものを散見す・顆粒は 概して微細狀にして周邊部に分布す.神經纎 維は常に正常にして他に著變を見す。

\section{第三章 綜括及び考按}

鹽酸レキニーネフ及びレサリチール酸 しナトリウムフによる聽梱經中樞系路に及 匢す病理組織學影響を觀るにその障碍領 域は略相等しく, その變性の程度は一般 にடサリチール7酸しナトリウムフは輕微な り. 郎,

珥㯖神經根に於ける蝸牛殼神經瀻維は

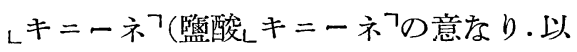
下之に準市)。第二節(小量を長期間投與 せし場合の所見）に於て變性最も著しく 纎維の排列不規則なり．染色は濃淡種々 にして鬆柾の狀を呈す. 前庭神經纎維は

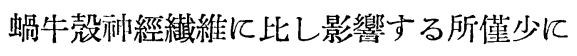
して第二節に於てのみ不規則なる排列及 び染色不良を認む。

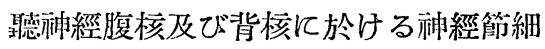


胞は形態的に變化しょキニーネフ及びしサ リチールフ酸(レサリチールフ酸レナトリウ ムフの意をり．以下之に準亦)共に第二節 第四節（一定度に減弱せし瞀覺の恢復せ し場合の所見）に於て萎箕するもの多く 第三節（大量を短期間に投與せし場合の

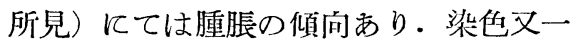
㥞ならず. 三ツスル氏小體の染色又不良 にして微細顆粒怢となり，周邊部に分布 し，或は中心性に集簇す。何れる第二節 第四節に於て核の崩壞するものあり．之 らの變化は一般に腹核に於て顯著なり. 神經纎維は蛇行匐行するるのを認む。

モナコウ，ヘルド氏兩愊線及び菱形體

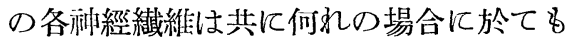
正常なり・レキニーネ第二節及び第四節 に小數のレマルキーר顆粒を認む。

上橔欖體に於ける胞體はレキニーネ第 四節しサリチール酸第三節第四節に於て 稍萎縮するもの西り。染色は一栐ならず して概して濃染す。ニツスル氏小體は一 般に染色不良にしてょサリチール酸第二 節にて顆粒の崩壤するものあり。

前庭神經核の胞體はょキニーネ第四節 レサリチール酸第三節第四節に於て萎縮 するるのを認む. 染色は概して濃染する る共に第四節に於ては淡染す. ニツスル 氏小體は主として微細顆粒狀こなり染色 は一定せず。神經纎維又一般に走行蛇行 状を呈するるのあり，排列の不規則なる を認む，但しサチール酸第三節は正労
なり。

顏面神經，三叉神經及外旋神經各核の 胞體は正常なり．レキニーネフ第二節第三 節第四箁レサリチール7酸第二節第三節に 於てはニツスル氏小體の染色不良なり。

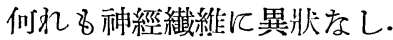

中腦，及び間腦に於ては第二節に於て 共に中腦の各神經細胞の胞體の稍萎縮す るものあるも他は凡て正常なり，概して ニツスル氏小體の染色不良なるを認めら る・神經繊維異䟮なし。

終腦に於てはょキニーネ第二節に於て 僅かに莠縮するものあるも他は凡て正常 なり.ニツスル氏小體の染色一樣ならず 概して濃染するが如し、神經繊維に暴狀 を認めず。

敍上の如くレキニーネフ及びレサリチー ルフ酸中毒に於ては㣜經節細胞の變性最 顯著にして就中第二節〔比較的小量 （レキニーネフ prokg. 0.01又は 0.02g.レサリ チールフ酸 prokg. 0.1g. を長期間（ょキニ ーネフ17-19日しサリチールフ酸12-13日） 投與せる場合】に於て最大とす、節細胞 は第二節に於て膨大するるのあるる萎縮 するを常とす，中樞經路に於ける變牲は 腹核及背核最8著明にして次で前庭神經 核，及び上橄欖體に於ける變性とす。之 らの病變を聽器に於ける螺旋神經節細胞 前庭神經節細胞及びコルチ氏器細胞等の 變性に比するに中樞經路に於ける變化は 概して輕度なるを常とす，即しキニーネフ 
長 澤 論 文 附 圖

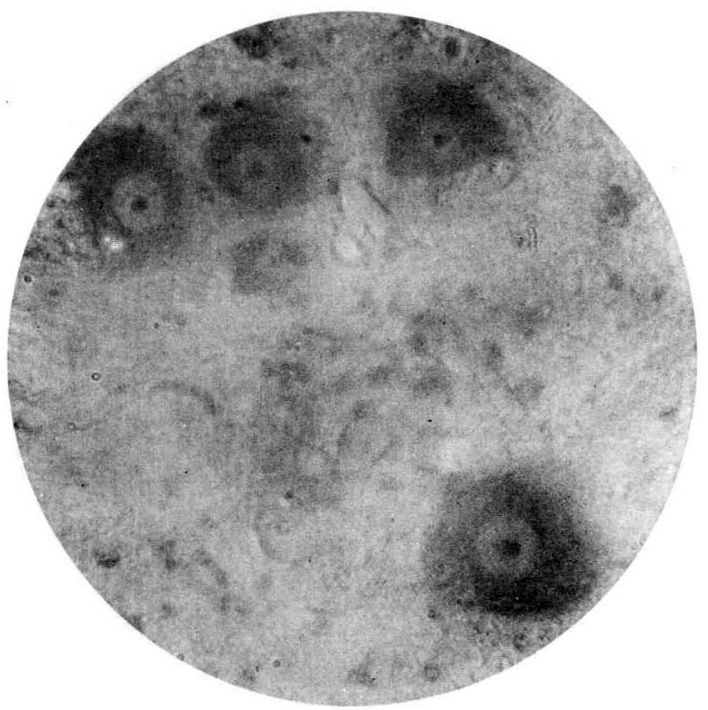

Fig. 1

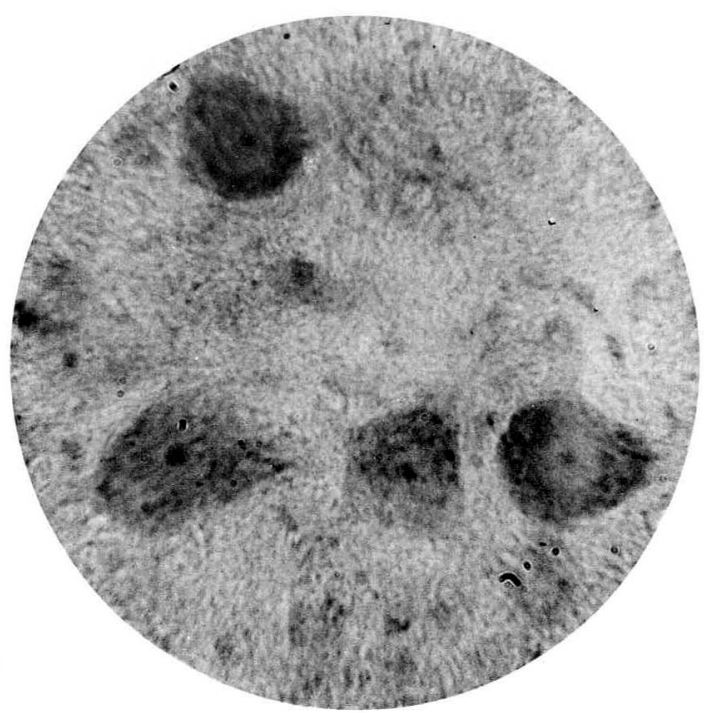

Fig. 2

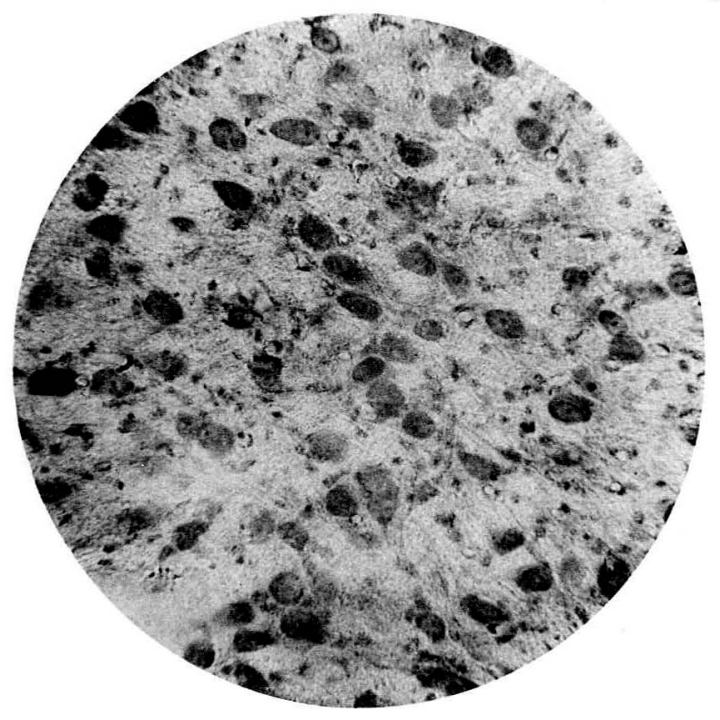

Fig. 3

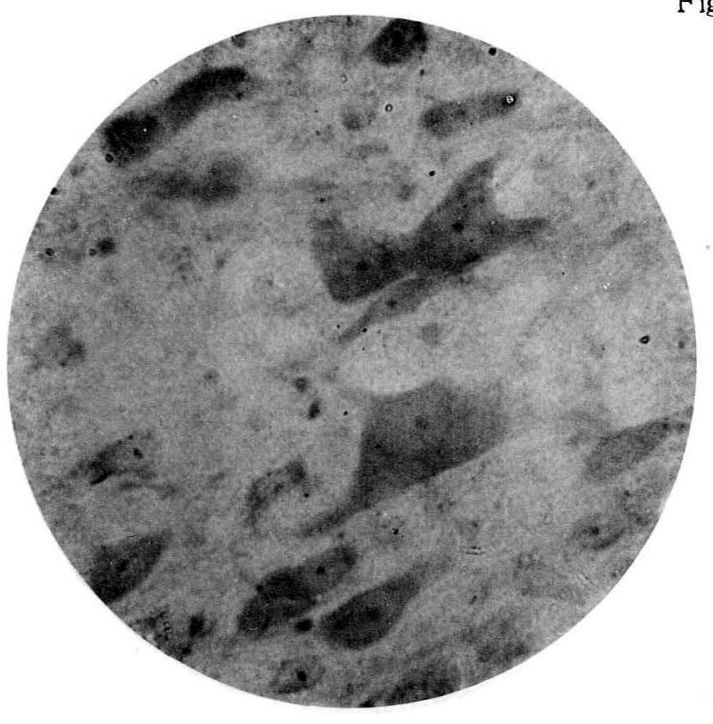

Fig. 4

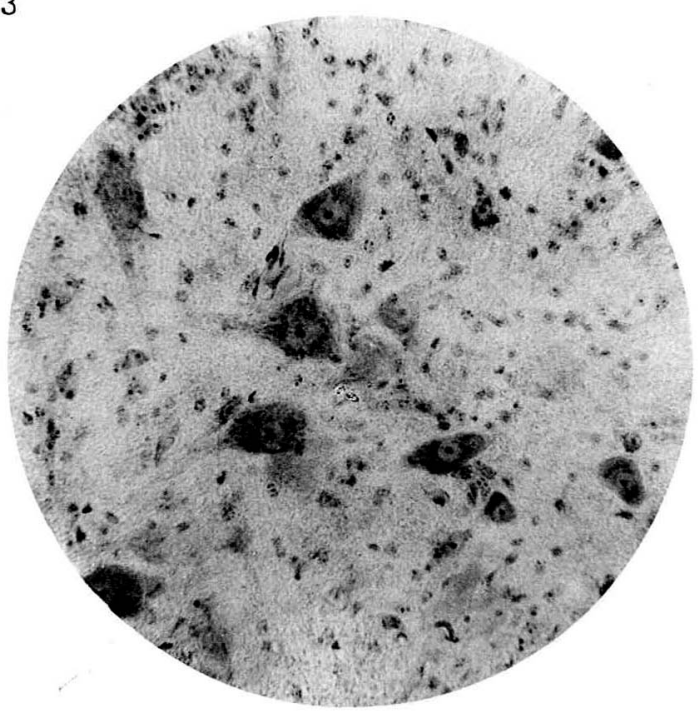

Fig. 5 
及びレサリチールフ酸による聽神經の變性 は末梢部位たる螺旋帆經節細胞最8顯著 にして次いで第一終止核たる腹核及び背 核なり，續いて漸次上位中慪に進むが如 し. 而して大腦䫑顬葉部皮質は最多僅微 なり・前庭神經系は蝸牛殼利經系に比し 一般にその變性輕度なり。

鹽酸レキニーネフ及び レサリチールフ酸 レナトリウム て關しては第三編第三章に於て詳述せし が如く現今に於ては略螺旋神經節細胞の 萎縮及び細胞のニツスル氏小體の崩壞消 失なりとの說を肯定されたるが如し. 然 れ共兩藥劑は共に生體に影響する所甚大 てして特に新陳代謝に關與する事深し。

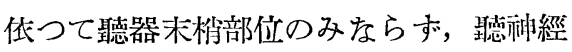
中樞經路に於ても變生の惹起せらる」は 想像に難からず．余の賽驗により兩藥劑 の中毒に際しては聽器未杪部位と共に雅 神經中樞部位でも各种經簡細胞の變牲を 來し，核變牲は蠌旋神經節細胞及び前庭 神經節細胞飞始亲り，冬朴經术妳部位及 中樞上位に進行するものと推察さる.

\section{第四章 結 論}

1. 鹽酸しキニーネフ及びレサリチールフ

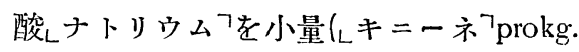
0.01 又は $0.02 \mathrm{gr}$. Lサリチール 酸 prokg. 0.1 又は $0.2 \mathrm{~g}$ ) を持續的に又は大量（ょキ ニーネフ prokg.0.09文は0.12gr·よサリチー ルフ酸 prokg. $0.8 \mathrm{gr}$ )を一特に投與すれば 罗点洲經中樞領域に於て 8 病變を惹起す。

2. 鹽酸しキニーネ双でレサリチールフ 酸レナトリウム?の小量又は中量( レキニー 亦 0.03 又は0.06，ᄂサリチールフ酸0.04) の投與により音響性耳殼反射の一定度に 減弱せし後該薬唯の投與を中止し，一定 期間を經て該耳殼反射の恢復せし場合に 於ても聽洲經中樞經路に病變を認む.

3. 篮酸しキニーネフ又はレサリチールフ 酸よナトリウムフの小量或は中量の長期間 投與による澺相經中樞經路に於ける病變 は大量一時に投與する場合に比し高度な b.

擱筆に當り恩師星野教授の御懇篤なる御指 導及御校閱に對して深甚の謝意を表す。

\section{附圖}

Fig. 1 聽神經背核

Fig. 2 政 核

Fig. 3 前庭神經核

Fig. 4 匋神經腹核

Fig 5 ダィテル氏核
（覽酸しキニーネフ小量長期間投與せし例）

[ri] I:

同 J:

（レサリチールフ酸しナトリウムフ大量を一時に投與せし例）

(監酸しキニーネフ大量を一時に投與せし例)

\section{主要 文 獻}

1) Alagna, Zeitschrıft. f. Ohıenh. Bd. 59 .

2) Alexander, Archiv. f. Ohrenh. Bd. 69. 3) Anitschkoff, Berichte f. gesammt. Physıl. u. Pharma Kol. Bd. 69. s. 95.

4) Anton-Halle, Denkel-Karl Bd. 6.

5) Blau, Archiv f. Ohrenh. Bd. 61. 
Beck, Zeitschrift f. Ohrenh. Bd. 68.

7) Brunner, Zentralblatt f. H. N. u. Kehl-Kopfh. Bd. 73 .

8) Bieferfeld, Archıv f. experi, Pathol. u Pharmakoli Bd. 79

Binz, Eulenburgs Realencyklop Bd. $31880 . \quad 10)$ Beck u. Jeseph, Archiv f. Ohienh. Bd. 63 .

11) Cooper, Journal of Physiologie Bd. 59. Nr. 4/5.

12) Derbney, Zeitschrift f. Ohrenh. Bd. $22 . \quad$ 13) Derselbe, Pflug. Archır f. die gesammte Physiologie Bd. $95 . \quad 14)$ Denkel-Karl, Bd. $6 . \quad 15)$ Grunnert, Archiv f. Ohrenh Bd. 45. 16) Giemsa, Munch. Med. Wochenschrıft. 1927. s. 574. 17) Heike, Archıv f. Obrenh. Bd. 63. 18) Heffter, Handbuch der experi. Pharmakologie. 19) Heubach, Archiv f. experi. Pathol. u. Pharmakol. Bd. 5. 20) Hanzlik, Journal of pharmak. Bd. 26 Nr. 1. 21) Knude, Archiv f. experi. Pathol. u. Pharmaknl. Bd. 78.

22)

Karl, Zeitscbrıft f. experi Pathol. u. Therap. Bd. $22 . \quad 23)$ Kirchner, Berl. Klınısch. Wochenschrift No. $491881 . \quad 24)$ Laroux-Robert, Zentralbl. f. F. N. u. Kehlkopfh. Bd. 16.2 25) Latzel, Wiener Klinisch. Wochenschrift 1921 Nr. 3/4.

Nelson, Bılog a. med. Bd. 25 Nr. 6.27 27) Aembosky, Archiv f. Ohrenh. Bd. 88. 28) Petrunkina, Bioch. Zertschrift. 213 419-423, $1923 . \quad 29)$ Santesson, Archiv f. experi. Pathol. u. Pharmakol. Bd. 32 . 30) Schwabach, Deut. med. Wochenschift. Nr. 11 1884. 31) Smorodinzew, Bioch. Zeitschuft. Bd. 183 8274. 1927.

Wunderlich, Archiv f. Ohrenh. Bd. 81. 33) Woschii, Zeıtschrift f. Ohrenh 58. 34) Wittmaack, Pflug. Archıv f. gesammt Physılogie Bd. 95.

Wittmaack, Archiv f. Ohrenl. Bd. 88. Physiol. u. Pharma. Bd. 60. s. 333.

36) Piccinini, Berichte $f$ gesamm Ohrenh. Bd. 73 .

入山, 大日本耳鼻咽喉科會報 32 劣.

37) Schroederin-Hinsberg, Zeitschrift $f$.

咽喉科京都臨床 15 卷.

松, 日本醫學輯報薬物學 5兊.

臺灣筧學會誌 30 卷, 31 管.

耳鼻咽喉科 京都臨床.

瀬, 日本內科學會誌 15 焂.

田中, 耳鼻咽喉科京都臨床 15 谷.

耳鼻咽喉科臨床 20 卷.

咽喉科會報 21 突.

56) 茂木, 臺灣噔學誌 31 卷.

耳鼻咽喉科臨床 23 春.

愛用，能本登掔會誌 8 谷。

40）細谷，大日本耳鼻咽喉科會報 19卷.

39）星野，耳鼻 42）小川，日本藥物學會報 10 卷-

44）小此木，日本藥物學會報 3 號，4號.

46）鳄淵，大日本耳鼻咽喉科會報 29 参. 48）吉田，耳鼻咽喉科臨床 20 卷 21 兴. 50) 中島, 日本藥物學會誌 3衮.

41) 平

43) 緒方,

45）脇田, 47）加

51) 亀谷,

53) 中村，大日本耳鼻 55）鈴木, 日本藥物學誌 12 姿.

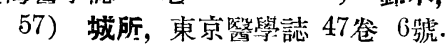

59）柳原, 耳鼻咽咴科臨床 29 卷.

58）仙石,

60）森島, 薬物學 